\title{
A semiconductive nature of bis(dithiolato)nickelate radical salt exhibiting broadband photoconduction
}

Wan-Wan Yao, ${ }^{a}$ Xiao-Yi Xu, ${ }^{a}$ Jin Zhang, ${ }^{a}$ Yin Qian, ${ }^{a}$ Jian-Lan Liu, ${ }^{* a}$ Xuan-Rong Chen ${ }^{\mathrm{b}}$ and Xiao-Ming Ren*a,c,d

${ }^{a}$ State Key Laboratory of Materials-Oriented Chemical Engineering and College of Chemistry \& Molecular Engineering, Nanjing Tech University, Nanjing 211816, P. R. China

b School of Chemistry \& Environmental Engineering and Instrumental Analysis Center, Yancheng Teachers University, Yancheng 224007, P. R. China

${ }^{c}$ College of Materials and Engineering, Nanjing Tech University, Nanjing 211816, P.

R. China

${ }^{d}$ State Key Laboratory of Coordination Chemistry, Nanjing University 210023, P. R. China

Phone: +8625 58139476

Fax: +8625 58139481

E-mail:xxren@njtech.edu.cn 


\section{Contents}

Figure S1: Experimental and simulated PXRD patterns of 1, in which the simulated PXRD pattern was obtained from the single crystal diffraction data using Mercury3.1 program.

Figure S2: (a) TG plot of 1 in 300-1073 K and (b) DSC curve of 1 in 180-373 K.

Figure S3: FT-IR spectrum of 1 in (a) $4000-500 \mathrm{~cm}^{-1}$ and (b) $1550-500 \mathrm{~cm}^{-1}$.

Figure S4: (a) A unit cell of 1 with two anions and two halves of cations, and each cation has the site occupation factor of 0.5 and two cations are related to each other by an inversion center (b) anion stack showing two anions per unit along $b$-axis (c) DiMIm $^{+}$arrangement viewed along $c$-axis $(d$, e) illustration of $\mathrm{S} \ldots \mathrm{S}$ contact interactions between $\left[\mathrm{Ni}(\mathrm{dmit})_{2}\right]_{2}{ }^{1-}$ dimeric chains in head-to-tail mode along the $\left[\begin{array}{ll}1 & 0\end{array}\right.$ 1] direction and in lateral-to-lateral manner along $b$-axis, where the blue dashed lines represent the S...S contacts less than $3.7 \AA$.

Figure S5: Temperature dependent $\chi_{\mathrm{m}}$ plots of 1, in which the open diamonds: experimental data; color lines: reproduced plots using fitted parameters, the red and blue lines are obtained from the fit by Eq. (1) and Eq. (2), respectively.

Figure S6: Temperature dependent (a-c) the real parts of AC and (d) DC conductivities in $183-373 \mathrm{~K}$.

Figure S7: UV-vis-Near IR solid diffuse reflection spectrum of 1 in the form of (a) wavelength and (b) wavenumber.

Figure S8: $(\mathrm{a}-\mathrm{c})$ Close-up view of the several highest occupied bands and lowest unoccupied bands, where the Fermi levels are shown by dashed lines, k-points: $\Gamma=(0$, $0,0), F=(0,0.5,0), Q=(0,0.5,0.5), Z=(0,0,0.5), X=(0.5,0,0.5), B=(0.5,0,0)$ and $(\mathrm{d}, \mathrm{e})$ total and partial density of states of $\mathbf{1}$.

Figure S9: The high symmetry directions of the Brillouin zone of $\mathbf{1}$.

Figure S10: Photocurrent of blank interdigital electrode under the bias of $0.1 \mathrm{~V}$ and irradiation by (a) green and (b) white lights. On/Off test of photocurrent of 1 under the bias of $0.1 \mathrm{~V}$ and irradiation by (c) UV and (d) blue lights. 
Table S1: Crystallographic data and refinement parameter for $\mathbf{1 .}$

Table S2: Bond lengths and angles for 1 at $299 \mathrm{~K}$.

Table S3: Comparison of the characteristic averaged bond lengths $(\AA)$ in $\left[\mathrm{Ni}(\mathrm{dmit})_{2}\right]^{\mathrm{n}-}(\mathrm{n}=0-2)$.

Table S4: The $A_{g}$ vibrational modes and frequencies $\left(\mathrm{cm}^{-1}\right)$ for $\left[\mathrm{Ni}(\mathrm{dmit})_{2}\right]^{\mathrm{n}-}$. The $\mathrm{A}_{\mathrm{g}}(1), \mathrm{A}_{\mathrm{g}}(2)$ and $\mathrm{A}_{\mathrm{g}}(3)$ modes are assigned to the $\mathrm{C}=\mathrm{C}$ stretching mode, the $\mathrm{C}=\mathrm{S}$ stretching mode, and the $\mathrm{C}-\mathrm{S}$ stretching mode, respectively.

\section{References}




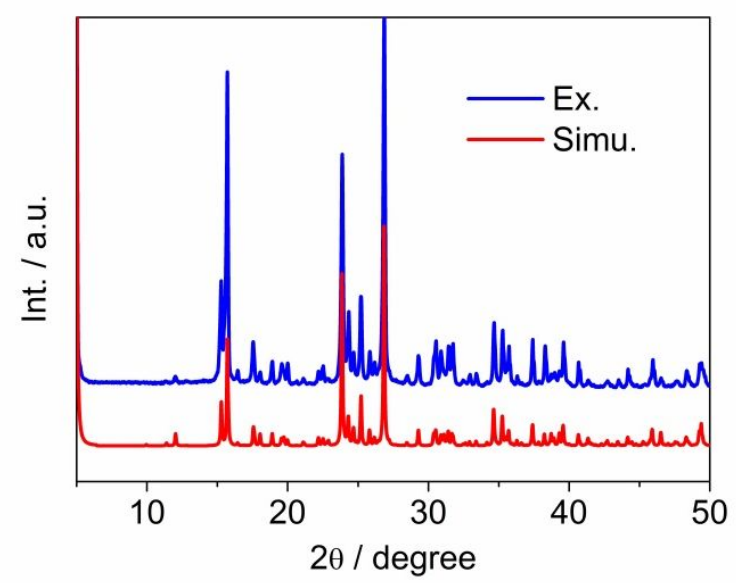

Figure S1: Experimental and simulated PXRD patterns of 1, in which the simulated PXRD pattern was obtained from the single crystal diffraction data using Mercury3.1 program.
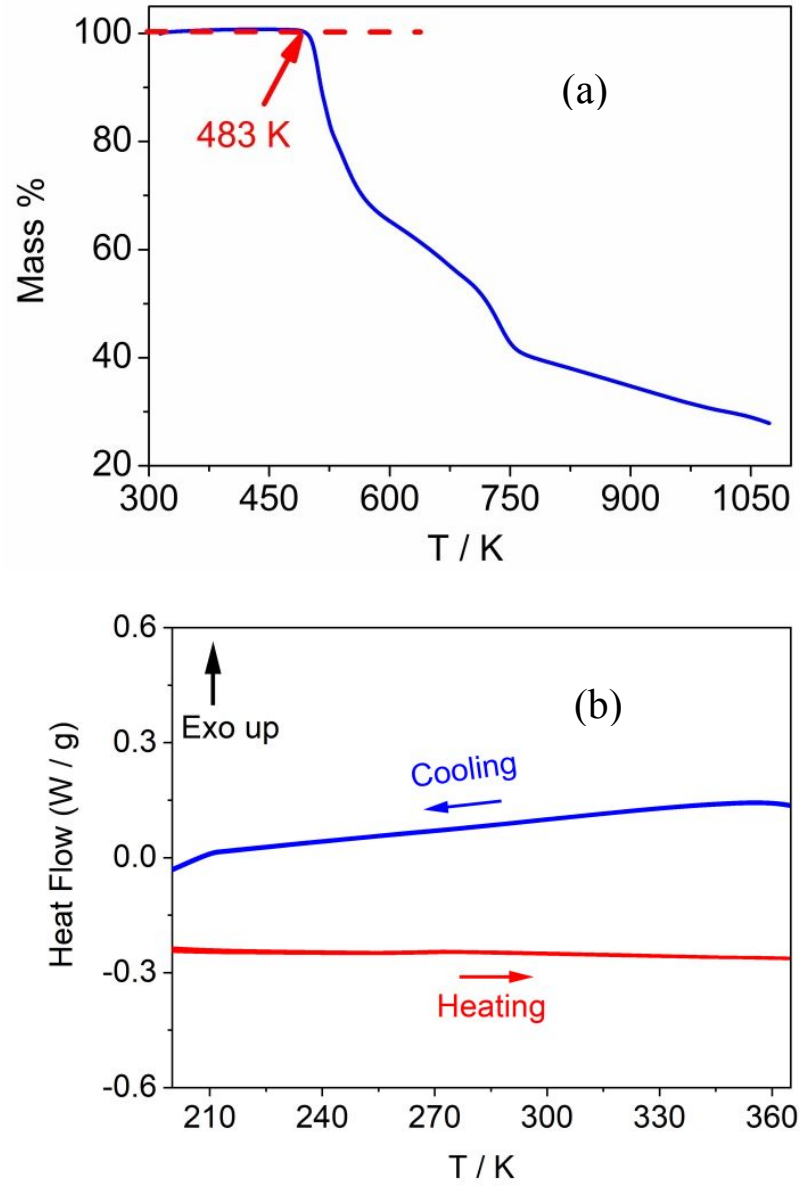

Figure S2: (a) TG plot of 1 in 300-1073 K and (b) DSC curve of 1 in 180-373 K. 

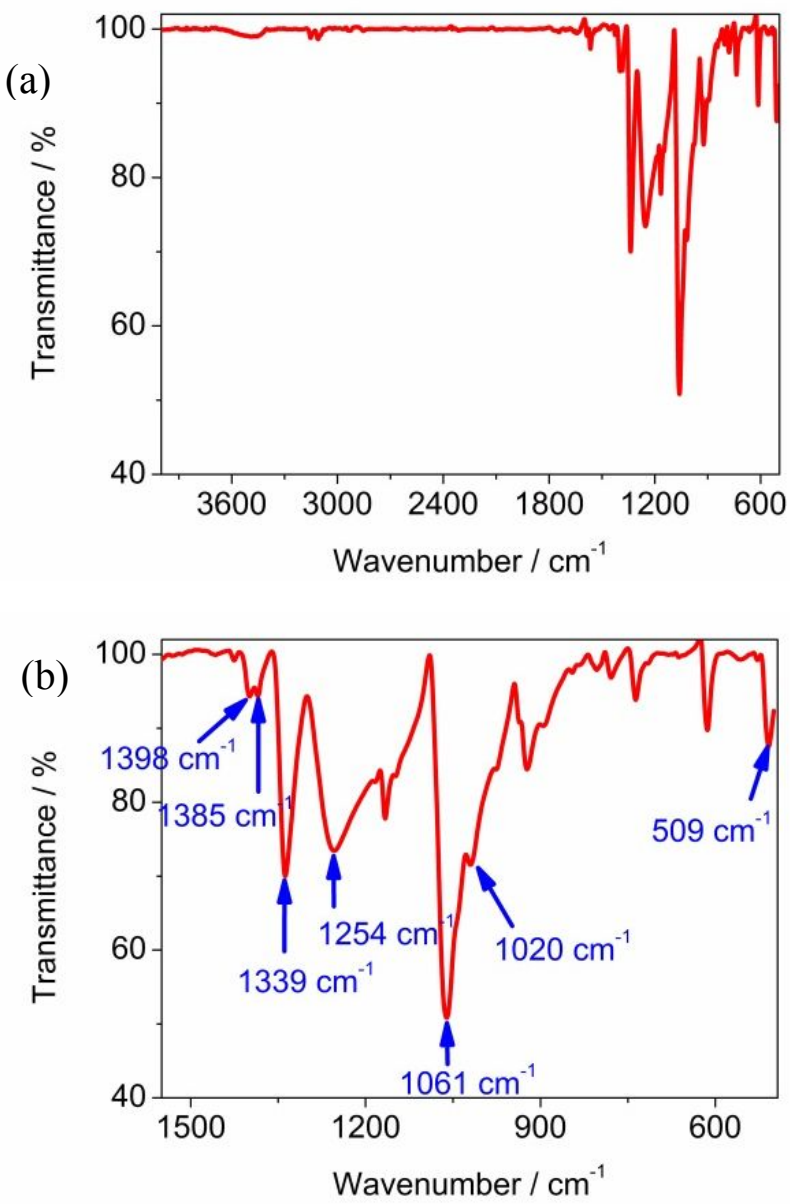

Figure S3: FT-IR spectrum of 1 in (a) $4000-500 \mathrm{~cm}^{-1}$ and (b) $1550-500 \mathrm{~cm}^{-1}$. 

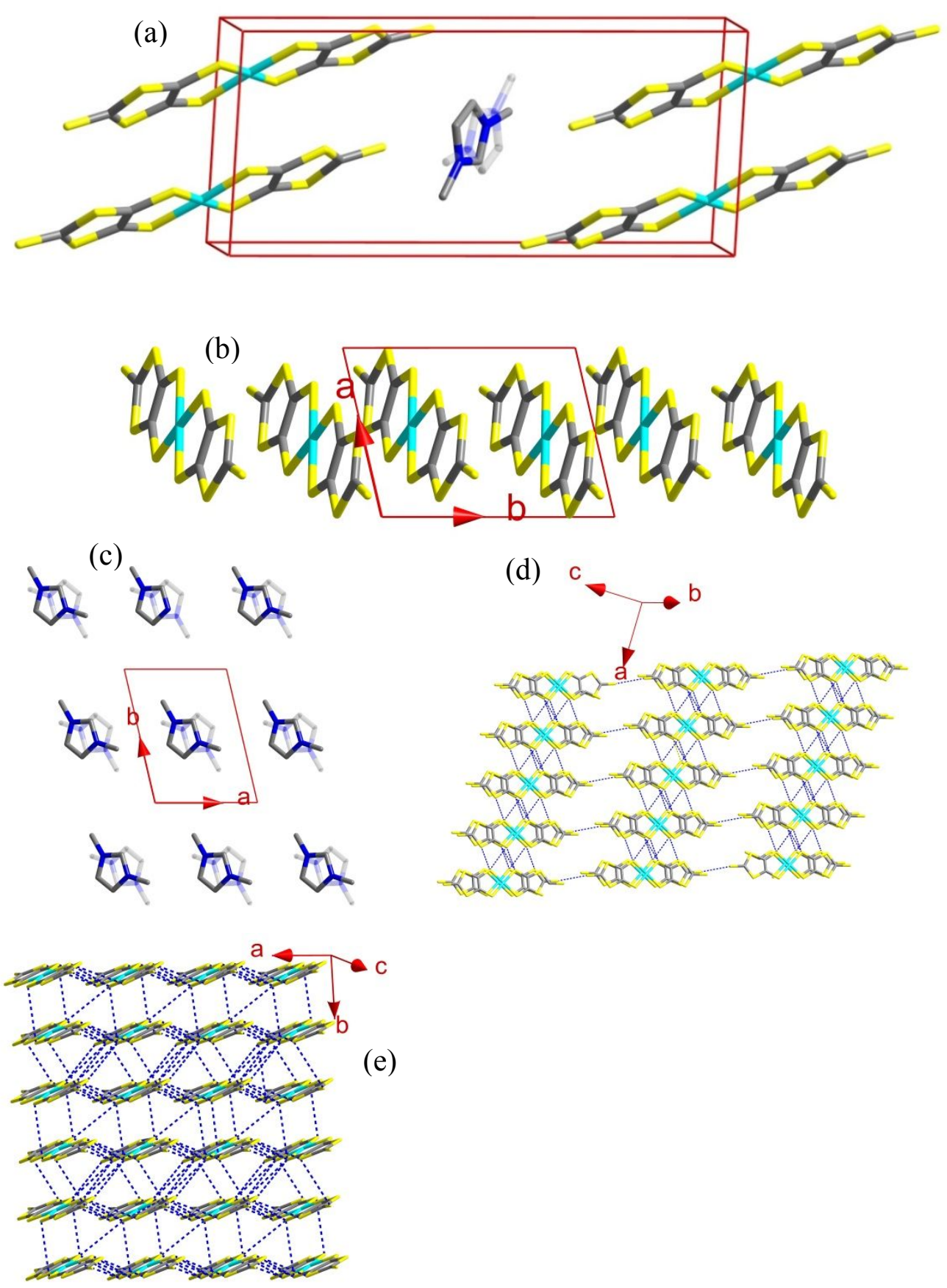

Figure S4: (a) A unit cell of 1 with two anions and two halves of cations, and each cation has the site occupation factor of 0.5 and two cations are related to each other by an inversion center (b) anion stack showing two anions per unit along $b$-axis (c) $\mathrm{DiMIm}^{+}$arrangement viewed along $c$-axis $(\mathrm{d}$, e) illustration of $\mathrm{S} \ldots \mathrm{S}$ contact interactions between $\left[\mathrm{Ni}(\mathrm{dmit})_{2}\right]_{2}{ }^{1-}$ dimeric chains in head-to-tail mode along the $\left[\begin{array}{ll}1 & 0\end{array}\right.$ 
1] direction and in lateral-to-lateral manner along $b$-axis, where the blue dashed lines represent the S...S contacts less than $3.7 \AA$.

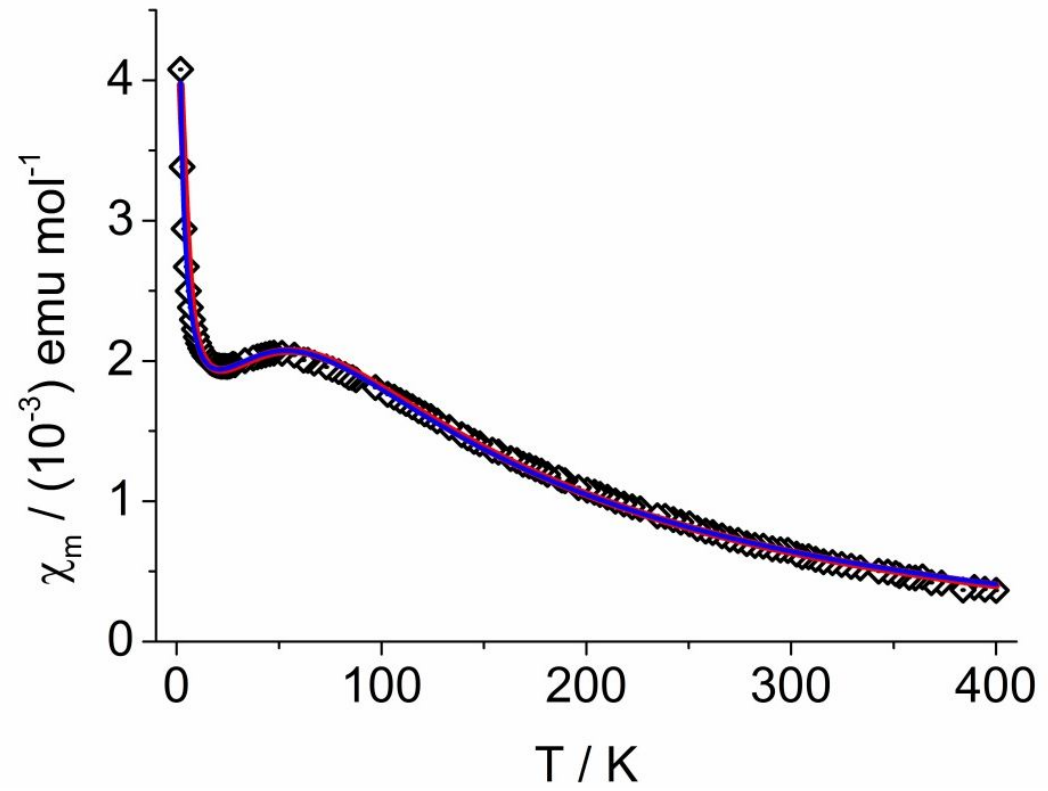

Figure S5: Temperature dependent $\chi_{\mathrm{m}}$ plots of 1, in which the open diamonds: experimental data; color lines: reproduced plots using fitted parameters, the red and blue lines are obtained from the fit by Eq. (1) and Eq. (2), respectively.

$\chi_{m}=\frac{N g^{2} \mu_{B}^{2}}{k_{B} T} \cdot \frac{A+B X+C X^{2}}{1+D X+E X^{2}+F X^{3}}+\frac{C}{T-\theta}+\chi_{0}$

$\chi_{m}=\frac{\chi_{\text {chain }}}{\left(1-\frac{n z J}{N g^{2} \mu_{B}^{2}} \chi_{\text {chain }}\right)}+\frac{C}{T-\theta}+\chi_{0}$

In Eq. (2), $\chi_{\text {chain }}$ is a uniform $S=1 / 2$ Heisenberg AFM linear chain and has expression in Eq. (3), and $\mathrm{zJ}$ is the interchain mean magnetic exchange constant, $\mathrm{n}$ is the number of the nearest neighboring chains and the value is 4 in this salt.

$\chi_{\text {chain }}=\frac{N g^{2} \mu_{B}^{2}}{k_{B} T} \cdot \frac{A+B X+C X^{2}}{1+D X+E X^{2}+F X^{3}}$ 

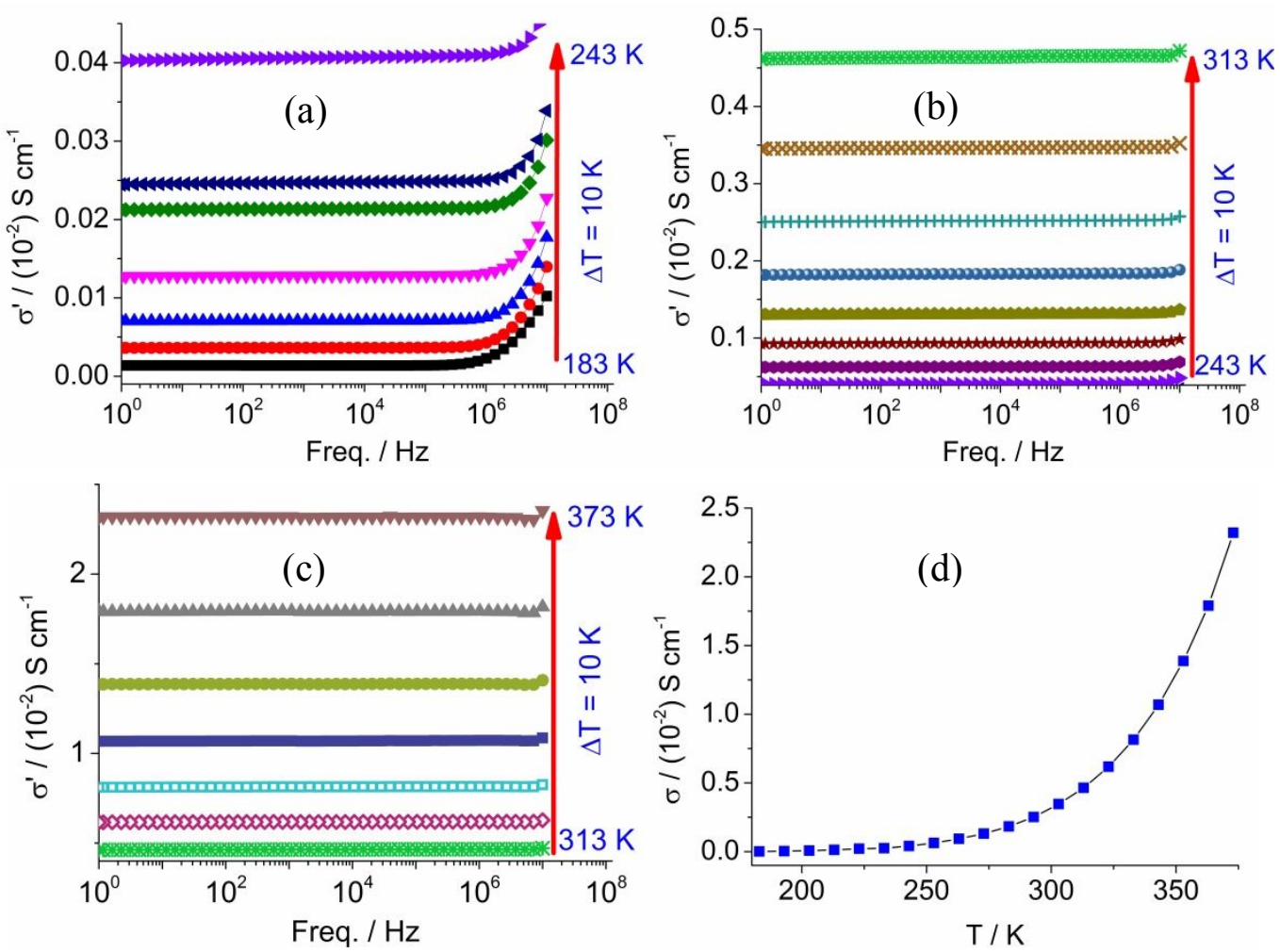

Figure S6: Temperature dependent (a-c) the real parts of AC and (d) DC conductivities in $183-373 \mathrm{~K}$.
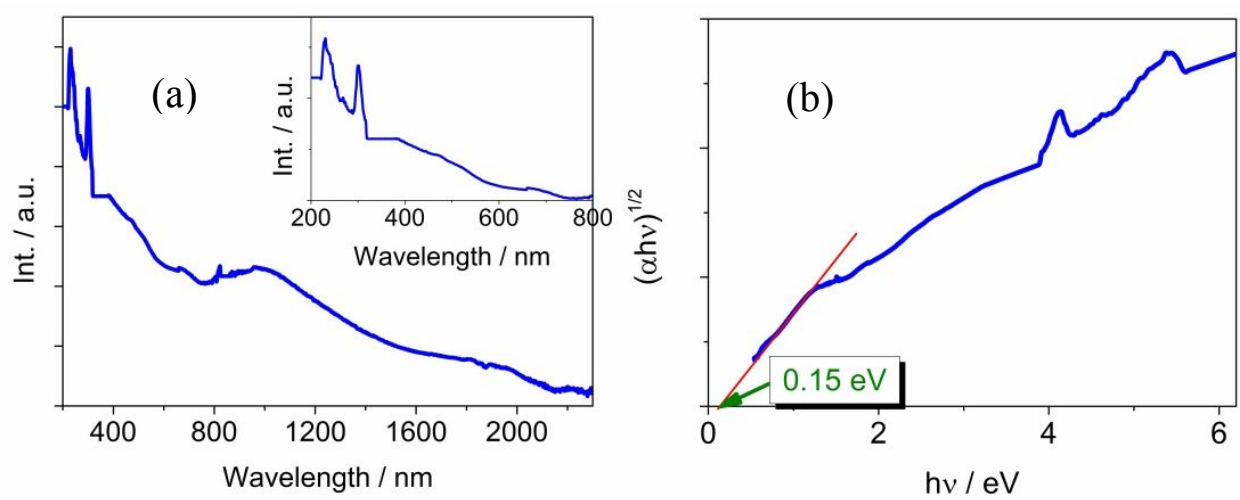

Figure S7: UV-vis-Near IR solid diffuse reflection spectrum of $\mathbf{1}$ in the form of (a) wavelength and (b) wavenumber. 

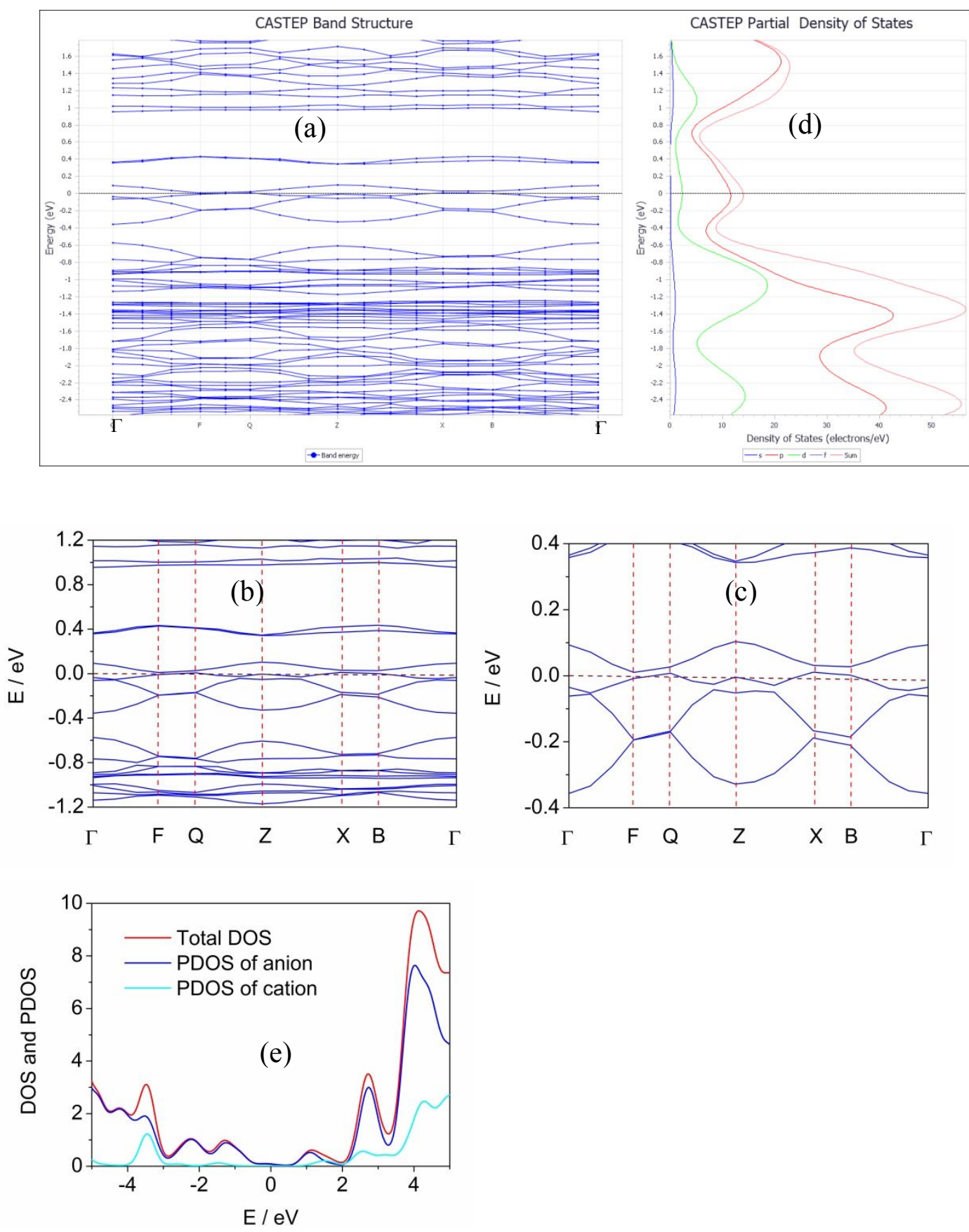

Figure S8: $(\mathrm{a}-\mathrm{c})$ Close-up view of the several highest occupied bands and lowest unoccupied bands, where the Fermi levels are shown by dashed lines, k-points: $\Gamma=(0$, $0,0), F=(0,0.5,0), Q=(0,0.5,0.5), Z=(0,0,0.5), X=(0.5,0,0.5), B=(0.5,0,0)$ and $(\mathrm{d}, \mathrm{e})$ total and partial density of states of $\mathbf{1}$. 


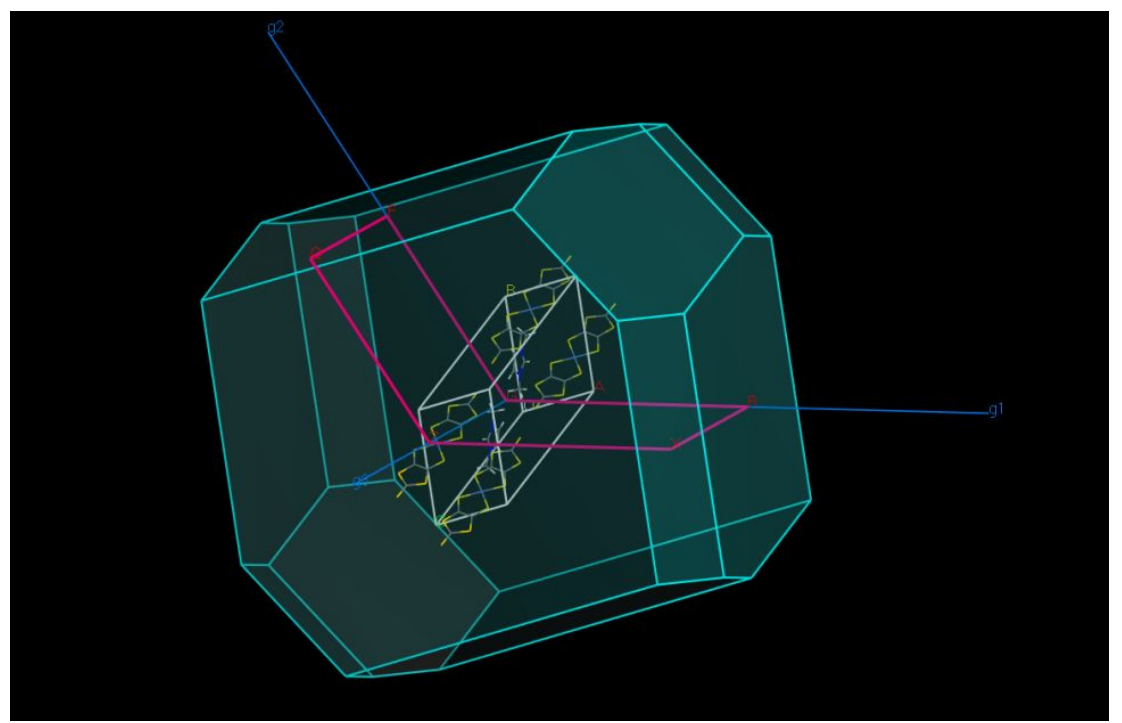

Figure S9: The high symmetry directions of the Brillouin zone of $\mathbf{1}$.
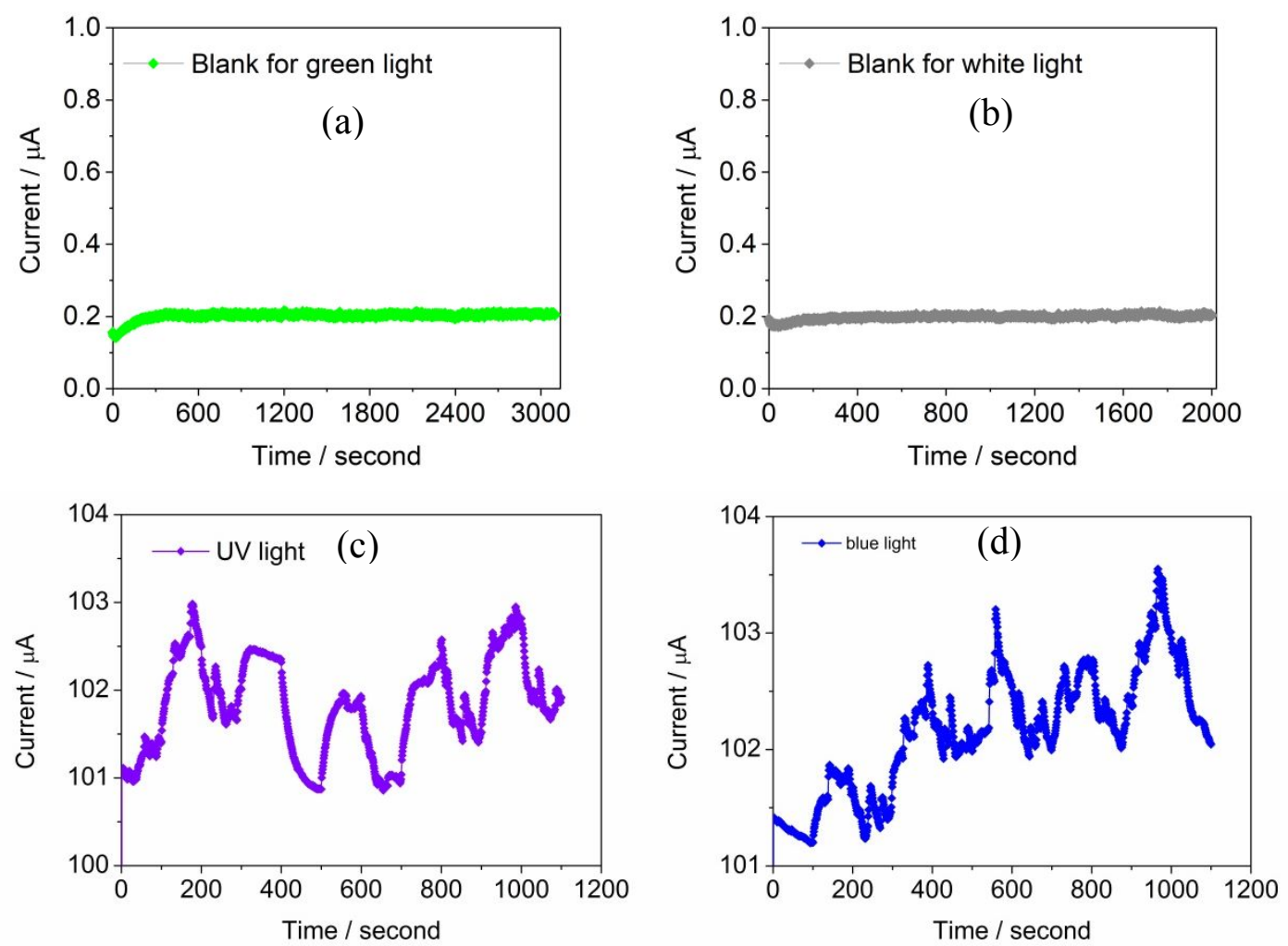

Figure S10: Photocurrent of blank interdigital electrode under the bias of $0.1 \mathrm{~V}$ and irradiation by (a) green and (b) white lights. On/Off test of photocurrent of 1 under the bias of $0.1 \mathrm{~V}$ and irradiation by (c) UV and (d) blue lights. 
Table S1: Crystallographic data and refinement parameter for $\mathbf{1 .}$

\begin{tabular}{|c|c|}
\hline Temp. / K & $299(2)$ \\
\hline Wavelength / $\AA$ & 0.71073 \\
\hline Formula & $\mathrm{C}_{17} \mathrm{H}_{9} \mathrm{~N}_{2} \mathrm{~S}_{20} \mathrm{Ni}_{2}$ \\
\hline Formula weight & 999.88 \\
\hline Space group & $P-1$ \\
\hline CCDC no. & 2030802 \\
\hline Crystal system & Triclinic \\
\hline$a / \AA$ & $5.9590(6)$ \\
\hline$b / \AA$ & $7.9892(7)$ \\
\hline$c / \AA$ & $17.8313(16)$ \\
\hline$\alpha /{ }^{\circ}$ & $94.002(3)$ \\
\hline$\beta /{ }^{\circ}$ & $93.359(3)$ \\
\hline$\gamma /{ }^{\circ}$ & $102.860(4)$ \\
\hline$V / \AA^{3}, \mathrm{Z}$ & $823.19(13) / 1$ \\
\hline$\rho / \mathrm{g} \cdot \mathrm{cm}^{-1}$ & 2.017 \\
\hline$\mu / \mathrm{mm}^{-1}$ & 2.432 \\
\hline$F(000)$ & 501 \\
\hline \multirow[t]{2}{*}{$\theta$ Range for data collection $\left(^{\circ}\right)$} & $2.625-25.498$ \\
\hline & $-7 \leq \mathrm{h} \leq 7$ \\
\hline \multirow[t]{2}{*}{ Index ranges } & $-9 \leq \mathrm{k} \leq 9$ \\
\hline & $-21 \leq 1 \leq 21$ \\
\hline $\mathrm{R}_{\text {int }}$ & 0.0414 \\
\hline Independent reflect. / restraints / parameters & $3064 / 0 / 211$ \\
\hline Refinement method & Full-matrix least-squares on $\mathrm{F}^{2}$ \\
\hline Goodness-of-fit on $F^{2}$ & 1.030 \\
\hline$R_{1}, w R_{2}{ }^{\mathrm{a}}[I>2 \sigma(\mathrm{I})]$ & $0.0369,0.0701$ \\
\hline$R_{1}, w R_{2}{ }^{\mathrm{a}}[$ all data $]$ & $0.0553,0.0744$ \\
\hline Residual / e $\cdot \AA^{-3}$ & $0.439 /-0.327$ \\
\hline
\end{tabular}


Table S2: Bond lengths and angles for 1 at $299 \mathrm{~K}$.

\begin{tabular}{llllll}
\hline Bond length / & & & & \\
$\mathrm{Ni}(1)-\mathrm{S}(4)$ & $2.1722(9)$ & $\mathrm{Ni}(1)-\mathrm{S}(5)$ & $2.1587(9)$ & $\mathrm{Ni}(1)-\mathrm{S}(6)$ & $2.1590(9)$ \\
$\mathrm{Ni}(1)-\mathrm{S}(7)$ & $2.1570(9)$ & $\mathrm{S}(1)-\mathrm{C}(1)$ & $1.657(3)$ & $\mathrm{S}(2)-\mathrm{C}(1)$ & $1.716(4)$ \\
$\mathrm{S}(2)-\mathrm{C}(2)$ & $1.742(3)$ & $\mathrm{S}(3)-\mathrm{C}(1)$ & $1.727(3)$ & $\mathrm{S}(3)-\mathrm{C}(3)$ & $1.744(3)$ \\
$\mathrm{S}(4)-\mathrm{C}(2)$ & $1.711(3)$ & $\mathrm{S}(5)-\mathrm{C}(3)$ & $1.703(3)$ & $\mathrm{S}(6)-\mathrm{C}(4)$ & $1.692(3)$ \\
$\mathrm{S}(7)-\mathrm{C}(5)$ & $1.694(3)$ & $\mathrm{S}(8)-\mathrm{C}(4)$ & $1.744(3)$ & $\mathrm{S}(8)-\mathrm{C}(6)$ & $1.731(3)$ \\
$\mathrm{S}(9)-\mathrm{C}(5)$ & $1.737(3)$ & $\mathrm{S}(9)-\mathrm{C}(6)$ & $1.728(3)$ & $\mathrm{S}(10)-\mathrm{C}(6)$ & $1.645(3)$ \\
$\mathrm{C}(7)-\mathrm{N}(1)$ & $1.450(12)$ & $\mathrm{C}(11)-\mathrm{N}(2)$ & $1.472(9)$ & $\mathrm{N}(1)-\mathrm{C}(8)$ & $1.323(4)$ \\
$\mathrm{N}(1)-\mathrm{C}(10)$ & $1.324(4)$ & $\mathrm{C}(9)-\mathrm{N}(2)$ & $1.323(4)$ & $\mathrm{N}(2)-\mathrm{C}(10)$ & $1.323(4)$ \\
$\mathrm{C}(2)-\mathrm{C}(3)$ & $1.371(4)$ & $\mathrm{C}(4)-\mathrm{C}(5)$ & $1.384(4)$ & $\mathrm{C}(8)-\mathrm{C}(9)$ & $1.324(4)$ \\
$\mathrm{Bond}$ angle $/ 0$ & & & & \\
$\mathrm{~S}(5)-\mathrm{Ni}(1)-\mathrm{S}(7)$ & $85.20(3)$ & $\mathrm{S}(5)-\mathrm{Ni}(1)-\mathrm{S}(6)$ & $177.96(4)$ & $\mathrm{S}(7)-\mathrm{Ni}(1)-\mathrm{S}(6)$ & $92.82(3)$ \\
$\mathrm{S}(5)-\mathrm{Ni}(1)-\mathrm{S}(4)$ & $93.30(3)$ & $\mathrm{S}(7)-\mathrm{Ni}(1)-\mathrm{S}(4)$ & $177.32(4)$ & $\mathrm{S}(6)-\mathrm{Ni}(1)-\mathrm{S}(4)$ & $88.69(3)$ \\
\hline
\end{tabular}

Table S3: Comparison of the characteristic averaged bond lengths ( $\AA$ ) in $\left[\mathrm{Ni}(\mathrm{dmit})_{2}\right]^{\mathrm{n}-} \quad(\mathrm{n}=0-2)$.

\begin{tabular}{llllll}
\hline Bond & $\mathrm{C}=\mathrm{C}$ & $\mathrm{Ni}-\mathrm{S}$ & $\mathrm{C}-\mathrm{S}^{*}$ & $\mathrm{C}=\mathrm{S}$ & Ref. \\
\hline $\mathrm{n}=-2$ & $1.353(3)$ & $2.195(5)$ & $1.733(2)$ & $1.735(2)$ & {$[2]$} \\
$\mathrm{n}=-1$ & $1.360(2)$ & $2.166(3)$ & $1.717(17)$ & $1.651(18)$ & {$[3]$} \\
$\mathrm{n}=-0.5$ & $1.383(6)$ & $2.164(1)$ & $1.701(5)$ & $1.653(6)$ & {$[4]$} \\
$\mathbf{n}=-\mathbf{0 . 5}$ & $\mathbf{1 . 3 7 8 ( 4 )}$ & $\mathbf{2 . 1 6 3 0 ( 9 )}$ & $\mathbf{1 . 7 0 0 ( 5 )}$ & $\mathbf{1 . 6 5 6 ( 3 )}$ & This work \\
$\mathrm{n}=0$ & $1.391(9)$ & $2.147(2)$ & $1.699(7)$ & $1.625(8)$ & {$[5]$} \\
\hline
\end{tabular}

*The $\mathrm{C}-\mathrm{S}$ bonds contain the $\mathrm{S}$ atoms bound to Ni center.

Table S4: The $A_{g}$ vibrational modes and frequencies $\left(\mathrm{cm}^{-1}\right)$ for $\left[\mathrm{Ni}(\mathrm{dmit})_{2}\right]^{\mathrm{n}-}$. The $\mathrm{A}_{\mathrm{g}}(1), \mathrm{A}_{\mathrm{g}}(2)$ and $\mathrm{A}_{\mathrm{g}}(3)$ modes are assigned to the $\mathrm{C}=\mathrm{C}$ stretching mode, the $\mathrm{C}=\mathrm{S}$ stretching mode, and the $\mathrm{C}-\mathrm{S}$ stretching mode, respectively.

\begin{tabular}{lllll}
\hline $\mathrm{n}$ & $\mathrm{A}_{\mathrm{g}}(1)\left(v_{\mathrm{C}=\mathrm{C}}\right)$ & $\mathrm{A}_{\mathrm{g}}(2)\left(v_{\mathrm{C}=\mathrm{S}}\right)$ & $\mathrm{A}_{\mathrm{g}}(3)\left(v_{\mathrm{C}-\mathrm{S}}\right)$ & Ref. \\
\hline 0 & 1329 & 1051 & 496 & {$[6]$} \\
1 & 1343 & 1064 & 507 & {$[7]$} \\
0.7 & 1250 & 1067 & - & {$[8]$} \\
0.25 & 1250 & 1062 & - & {$[9]$} \\
0.5 & 1284 & - & - & {$[10]$} \\
$\mathbf{0 . 5}$ & $\mathbf{1 2 5 4}$ & $\mathbf{1 0 6 1}$ & - & This work \\
\hline
\end{tabular}




\section{References}

1. Yang, H.; Liu, J. L.; Zhou, L. C.; Ren, X. M. Experimental and theoretical investigation of the magnetic and photoconductive nature of a novel twodimensional, mixed-valence bis(2-thioxo-1,3-dithiole-4,5-dithiolato)nickelate molecular solid. Inorg. Chem. Front. 2014, 1, 426-433.

2. Fun, H. K.; Sivakumar, K.; Zuo, J. L.; Yao T. M.; You, X. Z. A 2:1 mixture of tetrabutylammonium bis(4,5-dimercapto-1,3-dithiole-2-thionato)nickelate(II) and its 2-selenone analog. Acta Crystallogr. Sect. C, Cryst. Struct. Commun. 1996, 52, $312-315$

3. Mulder, M. J. J.; Kooijman, H.; Spek, A. L.; Haasnoot, J. G.; Reedijk, J. A new monoclinic crystal phase of $\left[\mathrm{Bu}_{4} \mathrm{~N}\right]\left[\mathrm{Ni}(\mathrm{dmit})_{2}\right]$. J. Chem. Cryst. 2002, 32, $347-351$

4. Cornelissen, J. P.; Loux, R. L.; Jansen, J.; Haasnoot, J. G.; Reedijk, J.; Horn, E.; Speck, A. L.; Pomarede, B.; Legros, J. P.; Reefman, D. Crystal structures, electrical conductivity and band-structure calculations of three new [cation] $\left[\mathrm{Ni}\left(\mathrm{C}_{3} \mathrm{~S}_{5}\right)_{2}\right]_{2}$ compounds. J. Chem. Soc. Dalton Trans. 1992, 2911-2921.

5. Valade, L.; Legros, J.-P.; Bousseau, M.; Cassoux, P.; Garbauskas, M.; Interrante, L. V. Molecular structure and solid-state properties of the two-dimensional conducting mixed-valence complex $\left[\mathrm{NBu}_{4}\right]_{0.29}\left[\mathrm{Ni}(\mathrm{dmit})_{2}\right]$ and the neutral [Ni(dmit $\left.)_{2}\right]\left(\mathrm{H}_{2}\right.$ dmit $=4,5$-dimercapto-1,3-dithiole-2-thione): Members of an electron-transfer series. J. Chem. Soc. Dalton Trans. 1985, 783-794.

6. Pokhodnya, K. I.; Faulmann, C.; Malfant, I.; Andreu-Solano, R.; Cassoux, P.; Mlayah, A.; Smirnov D.; Leotin, J. Infrared and Raman properties of [M(dmit $\left.)_{2}\right]$ (M=Ni, Pd) based compounds. Synth. Met. 1999, 103, 2016-2019. 
7. Cai, B.; Liu, J. L.; Sheng, X. L.; Ren, X. M. Observation of an unusual hysteretic magnetic transition in a heteroleptic nickel-bis-1,2-dithiolene compound. Inorg. Chem. Commun. 2011, 14, 1971-1974.

8. Sakamoto, Y.; Matsubayashi, G. E.; Tanaka, T. Preparation and properties of bis(oxalato)platinate and bis(1,3-dithiole-2-thione-4,5-dithiolato)metallate $(\mathrm{M}=$ nickel, palladium, and platinum) anion salts with the 1,4-diethylpyrazinium dication. Inorg. Chim. Acta 1986, 113, 137-141.

9. Papavassiliou, G. C.; Cotsilios, A. M.; Jacobsen, C. S. Spectroscopic investigation of metal dimercaptodithiolenes and selenium analogs. J. Mol. Struct. 1984, 115, 41-44.

10. Yoshida, Y.; Maesato, M.; Ishikawa, M.; Nakano, Y.; Hiramatsu, T.; Yamochi, H.; Saito, G. Charge-transfer solids using nucleobases: Supramolecular architectures composed of cytosine and $\left[\mathrm{Ni}(\mathrm{dmit})_{2}\right]$ assembled by multiple hydrogen bonds and heteroatomic contacts. Chem. Eur. J. 2013, 19, 12325-12335. 